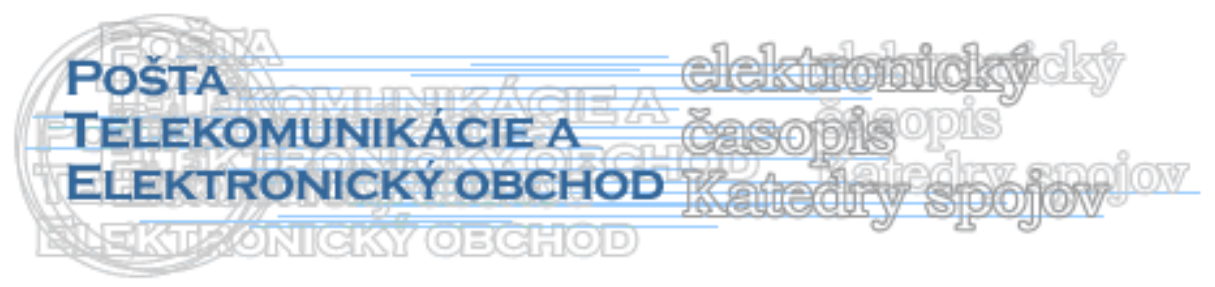

\title{
MANAŽÉR A MOBBING
}

\author{
Ján Gurský ${ }^{1}$, Renáta Fujdalová*
}

Úvod

Pojem „manažér“ a „mobbing“ v dnešnej dobe v praxi vel’mi úzko súvisia. Absolventi vysokých škôl, ktorí nastupujú na svoje prvé pracoviská, v určitom zmysle predstavujú hrozbu pre súčasných manažérov, zvlášt' pre tých menej kreatívnych, flexibilných, profesne a profesionálne málo zdatných. Preto tu často, aj ked' niekedy nevedomky, dochádza k mobbingu zo strany manažérov alebo starších kolegov.

\section{Manažér}

Prvý človek, s ktorým sa pracovník pri nástupe do zamestnania stretne, je manažér. Práve od neho sa očakáva, že vo vzt’ahu k zamestnanom na slušnej úrovni zvláda interpersonálne roly. On vysiela prvé signály, ktoré vplývajú na vytvorenie prvého dojmu, ktorý je neraz určujúci pri začínajúcom formovaní vzt'ahu nového zamestnanca k manažérovi, k podniku a k vykonávanej práci. Samozrejme, prvý dojem je dôležitý, ale skúsený manažér zvládnutím interpersonálnych rolí buduje trvalý pozitívny vzt'ah zamestnancov k podniku a značným dielom prispieva $\mathrm{k}$ priaznivej klíme na pracovisku.

Manažér by mal pozorne sledovat' adaptáciu nových zamestnancov v podniku. Ináč by sa má správat' $\mathrm{k}$ absolventovi, ktorý prichádza do podniku len s teoretickými vedomost'ami a pracovné zručnosti a schopnosti získava postupne a prakticky ho formuje jeho prvý pracovný kolektív vedený manažérom, a ináč ku staršiemu zamestnancovi, ktorý už $\mathrm{v}$ pracovnom procese bol. Je vel'kou chybou manažéra, ak očakáva od oboch prijatých pracovníkov rovnaké výkony, rovnaký čas na adaptáciu a napríklad absolventa neprimerane pozoruje, často nevhodne napomína, či ináč mu dáva najavo jeho neskúsenost'. Taktiež značne predíži adaptačný čas absolventa, ak mu nedá možnost' zapracovat' sa pod vedením skúseného pracovníka, ktorý podáva dobré výkony. Mnohí manažéri na tento fakt zabúdajú, prípadné ,zaškolenie“ zrealizujú počas desiatich minút, tak ako školenie o bezpečnosti pri práci. Takáto situácia prispieva k zvýšeným stresovým faktorom novoprijatého zamestnanca a prinajmenšom $\mathrm{k}$ zmätenému názoru na riadiace schopnosti manažéra.

Pre podnik je každý nový zamestnanec investíciou a predstavuje náklady, pretože spravidla musí absolvovat' kurzy, školenia a iné formy, zväčša externého vzdelávania. A každý nový pracovník potrebuje istý čas na zaškolenie a nejaký čas nie je stopercentne výkonný. Priamo pre kolektív, do ktorého bol nový pracovník včlenený, a pre manažéra konkrétneho pracoviska to znamená časté zastupovanie, možno obmedzenie dovoleniek iným zamestnancom, „strata“ času pri vysvetl'ovaní, naprávaní chýb a podobne. Ak kolektív a zvlášt' manažér tohto kolektívu nevidí perspektívne v novom kolegovi prínos, je postavenie

\footnotetext{
${ }^{1}$ Ing. Ján Gurský, SP, a.s.. SPFZ Obl. zastúpenie Prešov, tel.: 0911118 242, e-mail: gursky.jan@slposta.sk

* Mgr. Renáta Fujdalová, SP, a.s., Pošta Prešov 1, tel.: 0903442 578, e-mail: fujdalova.renata@slposta.sk
} 
tohto „nováčika“ nezávideniahodné a jeho presadenie sa v kolektíve a na pracovisku zvlášt’ zložité a t’ažké.

Manažér má byt' empatický, taktný, tolerantný a zároveň reprezentatívny, presvedčivý, čitatel'ný pre l'udí s rôznym vzdelaním a na rôznej intelektuálnej úrovni, a hlavne komunikatívny. Od manažéra sa vyžaduje profesionalita, ale aj dodržiavanie základných princípov správania sa k iným l'ud'om. Je chybou, ak je povýšenecký a rozhoduje len z pozície moci, zmysluplná otvorená komunikácia mu je cudzia, jeho názor na morálne hodnoty je zdeformovaný. Nepokúša sa nájst' obojstranne výhodné a prijatel'né riešenie, prienik záujmov. Vidí len záujem podniku - splnenie denného plánu. Pod týmto tlakom so zamestnancami komunikuje agresívne a nedovolí im, aby mu objasnili svoj problém, neprejaví ani najmenšiu známku l'udskosti. Dôsledky takéhoto nemorálneho konania manažéra sú dlhodobé. Ukrivdený a ponížený zamestnanec si ho prestáva vážit', je demotivovaný, získava k manažérovi trvalo negatívny vzt'ah, lebo ho nepochopil pri závažnom osobnom probléme.

Medzi hlavné morálne princípy $\mathrm{v}$ manažérskej etike by mali patrit' princíp zodpovednosti a úcty $\mathrm{k}$ človeku. Aj ked' manažérsku etiku nemožno zúžit' len na oblast' vzt'ahu manažéra a ostatných zamestnancov v pozícii podriadených, tento vzt’ah je a bude súčast'ou, ak nie dokonca základom d'alších špecifických činností riadiaceho procesu. Manažér musí hl'adat' riešenie situácie, pri ktorom zohl'adní okolnosti a má nájst' optimálne prepojenie medzi účelnost'ou, morálnou zásadovost'ou a humánnymi prostriedkami. Neodmyslitel'nou súčast'ou jeho vzt'ahu k zamestnancovi je empatia, schopnost' vcítit' sa do pozície iného človeka. Malo by to byt' súčast'ou každodenného života, či už osobného alebo pracovného.

Ako jeden z najvážnejších dôsledkov a problémov nemorálneho, v mnohých prípadoch až nel'udského zaobchádzania so zamestnancami, je strata sebadôvery zamestnancov a postupom času, aj pod vplyvom psychického nátlaku, až neschopnost' adekvátne reagovat' a protestovat' proti takémuto zaobchádzaniu. Zamestnanec sa cíti neistý, frustrovaný, stráca odvahu a časom správanie manažéra prijíma ako normu. Nevhodné a neuvážené správanie sa manažéra často nastáva i v súvislosti s prepúšt’aním zamestnancov. Nie prepúšt’anie ako prirodzený proces vývoja podniku, ktorý prebieha napr. zmenou organizačnej štruktúry alebo zlou ekonomickou situáciou, ale prepúšt’anie z osobných antipatií, z domáhania sa slušnejšieho finančného ohodnotenia, z čerpania neplánovanej dovolenky či z iných, často absurdných dôvodov. Dobrý manažér v riadiacom procese si uvedomuje, že nielen prijímanie nových zamestnancov, ale ani komunikácia a prepúšt’anie starých zamestnancov nemôžu byt' neuvážené.

Komunikácia je prvkom, ktorý integruje všetky ostatné do jednotného dynamického celku. V moderných podnikoch sú manažéri vzdelaní l'udia s tomu zodpovedajúcou rétorikou. Svoj slovník by však mali prispôsobit', hlavne čo sa týka cudzích a odborných slov, auditóriu. Ludia manažérovi musia v prvom rade rozumiet'. Neraz značným problémom je, že manažér nie je schopný hovorit' stručne, jasne a nevie pomenovat' podstatu problému. Vedomý si svojich kvalít a svojho postavenia vo firme mení svoje vystúpenie na rétorické cvičenie. Zamestnanci však od manažéra očakávajú niečo iné. Chcú jasne počut', čo konkrétne patrí ich osobe a ich pracovnej činnosti. Chcú vediet', ako majú naplnit' ciele organizácie a čo z nových podmienok vyplýva pre ich osobné ohodnotenie. Lebo, ak sa podiel'ajú na napín̆aní ciel'ov, chcú byt' morálne aj hmotne ohodnotení. Zamestnanci tiež potrebujú od svojich manažérov spätnú väzbu, podporu v profesionálnom raste. Chcú otvorene komunikovat' a chcú, aby ich myšlienky, návrhy a postoje manažér vypočul, zvážil a implementoval ich do celkovej činnosti organizácie. Často je pravdou, že manažéri vedia síce dobre hovorit', ale vôbec nevedia počúvat'. Manažér takto nedokáže získat' pracovníkov, aby boli voči firme lojálni, invenční, aby cítili za firmu a jej prosperitu spoluzodpovednost'. 
Naopak, sú aj takí manažéri, ktorí v procese riadenia využívajú úplne inú rétoriku. Snažia sa pracovníkov motivovat', podnecovat' $\mathrm{k}$ tvorivému výkonu práce a $\mathrm{v}$ žiadnom prípade svoj úsek neriadia tak, aby prišli o odborníkov.

Mladí manažéri, absolventi vysokých škôl sú teoreticky vel'mi dobre pripravení. Vedia pracovat' s informáciami, s novými technológiami, sú draví, zvedaví a sebavedomí. To je dobrý základ. Chýbajú im však praktické skúsenosti a mnohokrát trpezlivost'. Neboja sa riskovat', často však u nich absentuje miera zodpovednosti za svoje rozhodnutia tak v otázkach ekonomických, ako aj v otázkach morálky. Ich rozhodnutia sú pracovníkom prezentované nie najprijatel'nejšími spôsobmi, často netaktne. Neuvedomujú si, že s každou alternatívou súvisí zodpovednost' za rozhodnutie, ale aj zodpovednost' za následky rozhodnutia.

\section{Mobbing}

Mladí absolventi škôl pri nástupe do zamestnania očakávajú, že na pridelenom pracovisku a v zverenej funkcii využijú počas štúdia nadobudnuté vedomostí. V minulosti v mnohých prípadoch to tak naozaj aj bolo. Avšak zmenami, ktoré v našej spoločnosti nastali, $\mathrm{v}$ dobe, ked' začal fungovat' terajší model personálneho manažmentu, prvou a vel'mi náročnou úlohou absolventa školy je absolvovat' výberové konania a nájst' si zodpovedajúcu prácu.

Mnohí manažéri majú vo svojom tíme odborníkov, ktorí majú väčšie vedomosti, niekedy i vzdelanie a skúsenosti ako oni sami, čo niektorí z nich t’ažko znášajú a majú pocit ohrozenia. Z pohl'adu manažéra strednej úrovne riadenia predstavuje každý novoprijatý vysokoškolsky vzdelaný zamestnanec potenciálne ohrozenie jeho vlastnej funkcie. Preto sa niektorí manažéri svoje miesto snažia poistit' nečistými prostriedkami vyplývajúcimi z mobbingu, čo je šikanovanie a obt’ažovanie na pracovisku vyvíjaním psychického teroru. Ako pri šikanovaní, tak aj tu je konflikt medzi agresorom a obet'ou.

Mobbing na pracovisku je závažný problém. Podl'a odborníkov možno o mobbingu hovorit' vtedy, ked' je človek terorizovaný pravidelne aspoň jeden krát týždenne po dobu najmenej pol roka. Mobbing môže byt' medzi zamestnancami na jednej úrovni, ale ovel'a závažnejší je vtedy, ak agresorom je manažér. Osobné vlastnosti manažéra, jeho úroveň mravnej kultúry sú vel'mi dôležité a podstatnou mierou zvýšia alebo znížia úroveň riadenia. Manažér môže byt' výborný odborník, ale ak má vel'ké morálne medzery, vedie to $\mathrm{k}$ problémom a postupnému zaostávaniu firmy. Zamestnanci strácajú dôveru v neho i v seba navzájom, čo ovplyvňuje vzt’ahy, inovačné procesy, aktivitu, kreativitu. Zamestnanci sa stávajú bojazlivými, až nebezpečnými zo strachu, aby neboli pokarhaní za prípadný nezdar, zosmiešnení pred kolektívom, aby mobbing nezažili na vlastnej koži. Vel'mi citlivo vnímajú každý útok zo strany manažéra na svojho kolegu a sú schopní urobit' všetko pre to, aby sa terčom útoku nestali aj oni.

Pri súčasnom dynamickom tempe nie je možné, aby manažér ovládal všetky detailné problémy vo svojom odbore. Bojí sa však obklopit' odborníkmi, aby niekto nepoukázal na jeho „nevedomost““ alebo „neschopnost““. Nie je pripravený takéto napadnutia zvládnut' a racionálne vysvetlit'. Neuvedomuje si, že jeho úlohou je korigovat' a koordinovat' prácu, určovat' právomoci, pridel'ovat' zodpovednost'. „Správny šéf dokáže nadchnút' l'udí pre svoje zámery a znesie z ich strany aj kritiku. Vyrovná sa s neúspechmi bez toho, aby to ohrozilo jeho sebavedomie a navyše sa $z$ nich aj poučí.“

\section{Záver}

Ak manažér svojou rolou reprezentanta a vodcu nedokáže zamestnancov presvedčit', kolektív sa minimálne polarizuje a zamestnanci svoju prácu berú len ako nutné zlo a podnik 
ako inštitúciu, kde musia chodit’ a od ktorej raz mesačne dostávajú plat. „Umenie byt' manažérom a vodcom teda spočíva $\mathrm{v}$ schopnosti motivovat' spolupracovníkov k realizácii svojich zámerov. Nie je nutné zdôrazňovat', že v tomto úsilí hrá zásadnú úlohu fair play, vzájomná dôvera a etika.“

Manažér teda vykonáva aj interpersonálnu rolu „styčného dôstojníka“. Pôsobí ako spojovací most medzi manažérmi na rôznych úrovniach vo firme a medzi zamestnancami. Manažér na najnižšom stupni riadenia koordinuje prácu v záujme ciel’ov firmy a jej progresívneho rastu a manažérovi na vyššej úrovni podáva informácie a hl'adá riešenia v záujme firmy, no v súlade s možnost'ami jeho oddelenia a pracovníkov. Nesmie dopustit' mobbing na pracovisku a zanedbat' základné princípy l'udského správania.

Výsledky spoločnosti sa dajú dosiahnut' v atmosfére napätia, strachu, stresu, ale aj v atmosfére profesionality, dôvery, zodpovednosti, lojálnosti.

\section{Literatúra}

[1] LEIMAN, H.: The mobbing encyclopaedia, 2004.

[2] ŠVIDMOCHOVÁ, K.: Dobrý manažér dokáže l’udí počúvat'. In: Hospodárske noviny, 22.6.2006, s. 4.

[3] BLÁHA, J. - DYTRT, Z.: Manažerská etika. Praha: Managment Press, 2003, s. 118. 